\section{Vitamin D: the tricky hormone}

Victória Zeghbi Cochenski Borba'

$I^{n}$

$\mathrm{n}$ this issue of The Archives of Endocrinology and Metabolism two papers investigated

the impact of vitamin $\mathrm{D}$ in two different health conditions: one showed a negative result investigating the association of vitamin $\mathrm{D}$ levels with infertility and the other one the positive effect of vitamin D supplementation in the physiological lung function.

Vitamin D, a pre-hormone produced in the skin under sunlight exposure, undergoes various metabolic steps until its active form, 1,25-dihydroxyvitamin D3, is formed. The intermediary form, 25-hydroxyvitamin $\mathrm{D}$ (25OHD), is the recommended form for monitoring vitamin D status. The presence of l $\alpha$-hydroxylase (CYP27Bl) and the vitamin D receptor (VDR) in many cells indicates a possible local ability to synthesize 1,25-dihydroxyvitamin D3, the active metabolite of vitamin $\mathrm{D}$, which has turned the attention of the medical community to the noncalcemic effects of vitamin D (1). In recent decades, several studies have demonstrated the association of circulating 25OHD levels with different diseases, their activity, and health conditions. A positive association was found in several disorders such as systemic lupus erythematosus (SLE) and its activity (2); chronic obstructive pulmonary disease (COPD) (3); inflammatory bowel disease (IBD) (4); systemic sclerosis; endocrine disorders; cancer; immune; cardiovascular and other chronic diseases $(1,5)$; despite the presence of numerous positive observational studies, causation studies are lacking. A few good-quality randomized controlled studies on vitamin D supplementation in diverse disease endpoints show a modest effect on blood pressure, glycemic control, cancer, and immune response $(5,6)$.

Hypovitaminosis D is highly frequent worldwide and in Brazil, the prevalence ranges from $16 \%$ to $80 \%$ depending on the latitude and the population studied $(1,7)$. Although low levels of vitamin $\mathrm{D}$ are present in different diseases, infertile women studied in the article by Lopes and cols. (8) and also by others (9) did not show lower levels compared to controls. The literature in the field is ambiguous, showing both the importance of its adequate level and the lack of effect in infertility issues, such as polycystic ovary syndrome, endometriosis, myoma-induced infertility, male infertility, premature ovary failure and in vitro fertilization techniques $(10,11)$. Interestingly, however, Lopes and cols. (8) pointed out the high prevalence of hypovitaminosis D in a young premenopausal population, which is in agreement with the low vitamin D levels described for postmenopausal and older women in Brazil. Vitamin D and its level of impact on fertility is a matter to be defined. This controversy points out the wide effect of vitamin $\mathrm{D}$ and the need for a better understanding of its metabolism.

Nolasco and cols. (12) showed a positive effect of vitamin D on pulmonary function in healthy postmenopausal women participating in an aquatic exercise program. Low vitamin D levels were previously described in pulmonary diseases as well as their
1 Department of Internal Medicine, Universidade Federal do Paraná (UFPR); Serviço de Endocrinologia e Metabologia do Hospital de Clínicas da Universidade Federal do Paraná (SEMPR)

Correspondence to:

Victória Zeghbi Cochenski Borba Av. Agostinho Leão Junior, 285 80030-110 - Curitiba, PR, Brasil vzcborba@gmail.com

Received on Jan/25/2017 Accepted on Jan/25/2017

DOI: 10.1590/2359-3997000000250 
impact in the beginning and disease progression (13). However, studies examining the effect of vitamin supplementation on pulmonary diseases have shown diverse results. The response to tuberculosis treatment with and without vitamin D was not different $(14,15)$. Even though low vitamin D levels was associated with impaired lung function and to an inadequate response to treatment in patients with asthma, the addition of vitamin $\mathrm{D}$ did not modify the progression of the disease, compared to controls $(16,17)$. The study published in this issue, showing improvement in pulmonary function with vitamin $\mathrm{D}$, confirms once again the controversy around vitamin $\mathrm{D}$.

The controversy could be explained by diverse factors such as the lack of assessment of longterm, overall vitamin D intake as a dietary source, or a long-term evaluation of vitamin D levels; the sometimes unavailable measurement of inactive and active metabolites; the complexity of vitamin D metabolism and the variation of the methodology of measurement; and the high inter-individual variability in vitamin distribution between carrier proteins and target receptors (18). Many trials are ongoing in an attempt to clarify the impact of vitamin D in different physiological or medical aspects. Whether or not they succeed is a matter of debate due to the variability of protocols.

Considering all these aspects, we can give Vitamin D the title "The Tricky Hormone", as the medical community is challenged to clarify the real impact of this complex hormone.

Disclosure: no potential conflict of interest relevant to this article was reported.

\section{REFERENCES}

1. Maeda SS, Borba VZ, Camargo MB, Silva DM, Borges JL, Bandeira F, et al.; Brazilian Society of Endocrinology and Metabology (SBEM). Recommendations of the Brazilian Society of Endocrinology and Metabology (SBEM) for the diagnosis and treatment of hypovitaminosis D. Arq Bras Endocrinol Metabol. 2014;58(5):411-33.

2. Borba VZ, Vieira JG, Kasamatsu T, Radominski SC, Sato El, Lazaretti-Castro M. Vitamin D deficiency in patients with active systemic lupus erythematosus. Osteoporos Int. 2009;20(3):427-33.

3. Franco CB, Paz-Filho G, Gomes PE, Nascimento VB, Kulak CA, Boguszewski $C L$, et al. Chronic obstructive pulmonary disease is associated with osteoporosis and low levels of vitamin D. Osteoporos Int. 2009;20(11):1881-7.

4. Souza HN, Lora FL, Kulak CA, Mañas NC, Amarante HM, Borba VZ. [Low levels of 25-hydroxyvitamin D (25OHD) in patients with inflammatory bowel disease and its correlation with bone mineral density]. Arq Bras Endocrinol Metabol. 2008;52(4):684-91.

5. Rosen CJ, Adams JS, Bikle DD, Black DM, Demay MB, Manson JE, et al. The nonskeletal effects of vitamin D: an Endocrine Society scientific statement. Endocr Rev. 2012;33(3):456-92.

6. Forouhi NG, Menon RK, Sharp SJ, Mannan N, Timms PM, Martineau AR, et al. Effects of vitamin D2 or D3 supplementation on glycaemic control and cardiometabolic risk among people at risk of type 2 diabetes: results of a randomized double-blind placebo-controlled trial. Diabetes Obes Metab. 2016;18(4):392-400.

7. Arantes HP, Kulak CA, Fernandes CE, Zerbini C, Bandeira F, Barbosa IC, et al. Correlation between 25-hydroxyvitamin D levels and latitude in Brazilian postmenopausal women: from the Arzoxifene Generations Trial. Osteoporos Int. 2013;24(10):2707-12.

8. Lopes VM, Lopes JR, Brasileiro JP, Oliveira I, Lacerda RP, Andrade $M R$, et al. Highly prevalence of vitamin D deficiency among Brazilian women of reproductive age. Arch Endocrinol Metab. 2017;61(1):21-7.

9. Abadia L, Gaskins AJ, Chiu YH, Williams PL, Keller M, Wright DL, et al.; Environment and Reproductive Health Study Team. Serum 25-hydroxyvitamin D concentrations and treatment outcomes of women undergoing assisted reproduction. Am J Clin Nutr. 2016;104(3):729-35.

10. Dabrowski FA, Grzechocinska B, Wielgos M. The role of vitamin $D$ in reproductive health--a Trojan Horse or the Golden Fleece? Nutrients. 2015;7(6):4139-53.

11. Skowrońska P, Pastuszek E, KuczyńskiW, Jaszczoł M, Kuć P, Jakiel G, et al. The role of vitamin $D$ in reproductive dysfunction in women - a systematic review. Ann Agric Environ Med. 2016;23(4):671-6.

12. Nolasco R, Moreira LD, Bocalini DS, Fronza FC, Marin RV, LazarettiCastro M. Effects of vitamin D supplementation on pulmonary function in postmenopausal women following an aquatic exercise program. Arch Endocrinol Metab. 2017;61(1):28-35.

13. Hejazi ME, Modarresi-Ghazani F, Entezari-Maleki T. A review of Vitamin $D$ effects on common respiratory diseases: asthma, chronic obstructive pulmonary disease, and tuberculosis. J Res Pharm Pract. 2016;5(1):7-15.

14. Tukvadze N, Sanikidze E, Kipiani M, Hebbar G, Easley KA, Shenvi $N$, et al. High-dose vitamin D3 in adults with pulmonary tuberculosis: a double-blind randomized controlled trial. Am J Clin Nutr. 2015;102(5):1059-69.

15. Martineau AR, Timms PM, Bothamley GH, Hanifa $Y$, Islam $K$, Claxton $A P$, et al. High-dose vitamin $D(3)$ during intensive-phase antimicrobial treatment of pulmonary tuberculosis: a double blind randomized controlled trial. Lancet. 2011;377(9761):242-50.

16. Castro M, King TS, Kunselman SJ, Cabana MD, Denlinger L, Holguin F, et al.; National Heart, Lung, and Blood Institute's AsthmaNet. Effect of vitamin D3 on asthma treatment failures in adults with symptomatic asthma and lower vitamin D levels: the VIDA randomized clinical trial. JAMA. 2014;311(20):2083-91.

17. Sutherland ER, Goleva E, Jackson LP, Stevens AD, Leung DY. Vitamin D levels, lung function, and steroid response in adult asthma. Am J Respir Crit Care Med. 2010;181(7):699-704.

18. Musteata FM. Making sense of vitamin D concentrations. Future Sci OA. 2016;2(1):FSO90. 